\title{
Five new species of the Drosophila tripunctata group (Diptera: Drosophilidae) from Podocarpus National Park, Ecuador
}

\author{
Ana Danitza PEÑAFIEL-VINUEZA ${ }^{1, *} \&$ Violeta RAFAEL ${ }^{2}$ \\ ${ }^{1,2}$ Laboratorio de Genética Evolutiva, Facultad de Ciencias Exactas y Naturales, Pontificia Universidad \\ Católica del Ecuador, Av. 12 de Octubre y Roca, Aptdo. 17-01-2184, Quito, Ecuador. \\ *Corresponding author: adpenafiel@puce.edu.ec \\ ${ }^{2}$ Email: vrafael@puce.edu.ec \\ ${ }^{1}$ urn:1sid:zoobank.org:author:AA6AB8E4-4693-4F78-A563-7D911653FB1F \\ ${ }^{2}$ urn:lsid:zoobank.org:author:F1427026-0505-4267-A662-C47DCAE4109C
}

\begin{abstract}
Five new species of the genus Drosophila Fallén, 1823 belonging to the tripunctata group are described and illustrated: $D$. warmi sp. nov., D. kurillakta sp. nov., D. chichu sp. nov., D. saraguru sp. nov. and $D$. ayauma sp. nov. from the forests of Podocarpus National Park. The first species is ascribed to subgroup II of Frota-Pessoa (1954), the second species to subgroup IV, and the last three species are not assigned to any subgroup. The flies were captured using plastic bottles containing pieces of yeast fermented banana.
\end{abstract}

Keywords. Cloud forest, tripunctata radiation, terminalia, southern Ecuador, taxonomy.

Peñafiel-Vinueza A.D. \& Rafael V. 2019. Five new species of the Drosophila tripunctata group (Diptera: Drosophilidae) from Podocarpus National Park, Ecuador. European Journal of Taxonomy 494: 1-18.

https://doi.org/10.5852/ejt.2019.494

\section{Introduction}

The tripunctata group of Drosophila Fallén, 1823 was proposed by Sturtevant (1942). The group is endemic to the Neotropical Region where it represents the second largest species group, surpassed only by the D. repleta species group (Vilela 1992). The tripunctata group contains 84 species (Bächli 2018). Studies based on morphological characters made by Frota-Pessoa (1954) divided the group into four subgroups. Subgroup I is transitional to the guarani group. Subgroup II is the most typical of the group. Subgroup III has some species that are transitional to the cardini group. Some species belonging to subgroup IV have some affinities to the cardini group; they have white faces like some members of the cardini group (Frota-Pessoa 1954). Throckmorton (1975) proposed a pattern of radiation of Drosophila that included the tripunctata group, as well as the D. calloptera Freire-Maia \& Pavan, 1949, D. cardini Sturtevant, 1942, D. rubifrons Patterson \& Wheeler, 1942, D. guarani Dobzhansky \& Pavan, 1943, D. macroptera Patterson, 1943, D. pallidipennis Patterson \& Stone, 1952 and D. sticta Clayton \& Wheeler, 1975 species groups. Phylogenetic studies made by Hatadani et al. (2009) included several species of the tripunctata, guarani and other closest species groups. Their results did not support the 
monophyly of the tripunctata group, agreeing with Throckmorton (1975), Yokoto et al. (2003) and Robe et al. (2005). However, their results support a monophyletic origin for the immigrans-tripunctata radiation.

So far, a total of 28 species belonging to the tripunctata group have been collected in Ecuador: D. arcosae Vela \& Rafael, 2001, D. bandeirantorum Dobzhansky \& Pavan, 1943, D. carlosvilelai Vela \& Rafael, 2001, D. condorhuachana Céspedes \& Rafael, 2012, D. cuaso Bächli, Vilela \& Ratcov, 2000, D. cuyuja Ramos \& Rafael, 2015, D. fontdevilai Vela \& Rafael, 2001, D. ichubamba Vela \& Rafael, 2005, D. johnstonae Pipkin \& Heed, 1964, D. loewi Vilela \& Bächli, 2000, D. napoensis Ramos \& Rafael, 2015, D. ninarumi Vela \& Rafael, 2005, D. machachensis Vela \& Rafael, 2001, D. mediopicta Frota-Pessoa, 1954, D. mediosignata Dobzhansky \& Pavan, 1943, D. mesostigma Frota-Pessoa, 1954, D. metzii Sturtevant, 1921, D. paraguayensis Duda, 1927, D. pasochoensis Vela \& Rafael, 2001, D. patacorona Vela \& Rafael, 2005, D. pilaresae Vela \& Rafael, 2001, D. quijos Ramos \& Rafael, 2015, D. quillu Vela \& Rafael, 2005, D. roehrae Pipkin \& Heed, 1964, D. surucucho Vela \& Rafael, 2005, D. tomasi Vela \& Rafael, 2001, D. urcu Vela \& Rafael, 2005 and D. valenciai Vela \& Rafael, 2001.

The presence of median spots on the tergites was considered to be the main character of the tripunctata group (Frota-Pessoa 1954). Species identification within the tripunctata group has been difficult due to intraspecific variation of the bands and spots on the distal tergites (Vilela 1992). In addition to the variation in abdominal spotting, the species of this group are characterized by the mesonota lacking markings, a carina that is never sulcate, a dorsal arch connecting the arms of the hypandrium and cerci separated from the epandrium (Frota-Pessoa 1954).

We describe five new species of Drosophila belonging to the tripunctata group: D. warmi sp. nov., D. kurillakta sp. nov., D. chichu sp. nov., D. saraguru sp. nov. and D. ayauma sp. nov. We include illustrations and photographs of these new species. The similarities between the new species and those within the tripunctata group previously described are discussed.

\section{Material and methods}

The flies were collected in Loja and Zamora Chinchipe Provinces of Ecuador, in the cloud forests of the Podocarpus National Park and nearby localities. Collections were made at four high altitude localities: Bombuscaro at $1000 \mathrm{~m}$ a.s.1. $\left(04^{\circ} 06^{\prime} 59.8^{\prime \prime} \mathrm{S}, 78^{\circ} 58^{\prime} 04.9^{\prime \prime} \mathrm{W}\right)$, San Francisco at $2190 \mathrm{~m}$ a.s.l. $\left(03^{\circ} 59^{\prime} 16.7^{\prime \prime} \mathrm{S}, 79^{\circ} 05^{\prime} 35^{\prime \prime} \mathrm{W}\right)$ and Cajanuma at $2675 \mathrm{~m}$ a.s.1. $\left(04^{\circ} 06^{\prime} 53.7^{\prime \prime} \mathrm{S}, 79^{\circ} 10^{\prime} 54.6^{\prime \prime} \mathrm{W}\right)$ and 2800 $\mathrm{m}$ a.s.1. $\left(04^{\circ} 06^{\prime} 58.9^{\prime \prime} \mathrm{S}, 79^{\circ} 10^{\prime} 11.9^{\prime \prime} \mathrm{W}\right)$. Fifteen fermented banana traps were placed at each location ten meters apart from each other and a maximum of one meter above the base of the trees. Traps were made using recycled $500 \mathrm{ml}$ plastic bottles and baited with banana pieces fermented with yeast for 24 hours.

Living flies were captured with an entomological aspirator and transferred to vials with gelatin-banana media (Rafael et al. 2000). Females were individually isolated to produce isofemale lines. Adult males and dead flies were preserved in microcentrifuge tubes with ethanol (70-80\%) and glycerin (100\%) solution (Márquez-Luna 2005). The baits were removed from the traps and put inside glass jars sealed with cotton plugs. This material was transported to the laboratory where the baits were kept until the emergence of adult flies.

The external morphology of each fly was examined under a stereo microscope (Zeiss, Discovery V8). Male and female terminalia were dissected and placed in $\mathrm{KOH}(10 \%)$ and boiled for ten minutes. The genitalia were then placed in $60 \%$ glycerin for females and $100 \%$ for males. Terminalia were analyzed and compared with the available literature to determine new species. The new species were illustrated using a microscope (Zeiss-46 70 86) with a camera lucida (Zeiss-47 4620 9900). Structure measurements were made using the Axio Vision V4 software. Descriptive terms and indices follow the system of Bächli et al. (2004). 
The holotypes and paratypes of the new species have been deposited in the Museo de Zoología Invertebrados, Pontificia Universidad Católica del Ecuador, Quito (QCAZ-I).

\title{
Results
}

\author{
Class Insecta Linnaeus, 1758 \\ Order Diptera Linnaeus, 1758 \\ Family Drosophilidae Rondani, 1856 \\ Genus Drosophila Fallén, 1823 \\ Subgenus Drosophila Sturtevant, 1942 \\ Drosophila tripunctata species group sensu Sturtevant 1942 \\ Subgroup II sensu Frota Pessoa 1954 \\ Drosophila warmi sp. nov. \\ urn:1sid:zoobank.org:act:F64D7E97-D209-4D70-B011-493B438BFE59
}

Figs 1-3

\section{Diagnosis}

Aristae with six dorsal and three ventral branches, plus terminal fork. Prominent vibrissa. Thorax yellowish brown. Wings transparent yellow, bM-Cu slightly clouded. Male abdomen yellow with dorsal midline, $2^{\text {nd }}$ to $4^{\text {th }}$ tergites with thin pigmented bands, $5^{\text {th }}$ tergite without pigmentation and $6^{\text {th }}$ with a median spot. Female abdomen yellow with dorsal midline, $1^{\text {st }}$ tergite yellow, $2^{\text {nd }}$ to $4^{\text {th }}$ tergites with thin pigmented bands, $5^{\text {th }}$ and $6^{\text {th }}$ with a median spot between both tergites. Cerci not fused to epandrium. Hypandrium shield-shaped. Gonopod bearing one thick bristle. Paraphyses fused to gonopod bearing one small bristle. Aedeagus tubular and bifid, with two lateral sclerotized and serrated projections, and two ventral membranous enlargements covered in bright studs. Spermatheca balloon-shaped, with a distal dimple covered in short spines.

\section{Etymology}

In the Kichwa language, 'warmi' refers to 'woman'. The species name is in honor of Ecuadorian women.

\section{Material examined}

\section{Holotype}

ECUADOR $\bullet ~+$ (dissected, terminalia in microvial, dry mounted); Zamora Chinchipe Prov., Bombuscaro, 1000 m a.s.l.; 0406'59.8" S, 78 58'04.9" W; 23 Apr. 2015; A. Peñafiel leg.; A. Peñafiel and V. Rafael det.; QCAZ-I 3344.

\section{Allotype}

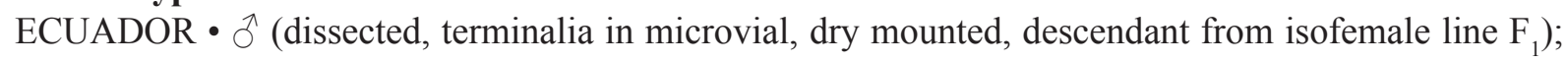
same data as for holotype; QCAZ-I 3345.

\section{Paratypes}

ECUADOR $\bullet 8$ 우 $q$ (dissected, terminalia in microvial, dry mounted, from among 24 descendants from isofemale line $\mathrm{F}_{1}$ ); same data as for holotype; QCAZ-I 3347 to $3354 \cdot 1$ o (dissected, terminalia in microvial, dry mounted, descendant from isofemale line $\mathrm{F}_{1}$ ); same data as for holotype; QCAZ-I 3346.

\section{Description}

\section{Female}

The female was chosen as the holotype for this species because both males are in poor condition. Holotype external morphology: total length (body + wings) $4 \mathrm{~mm}$, body length $3 \mathrm{~mm}$. Body color yellow. 
HEAD. Aristae with six dorsal and three ventral branches, plus terminal fork and fine hairs. Head with orbital plate yellowish brown, frontal length $0.27 \mathrm{~mm}$, frontal index $=0.61$, top to bottom width ratio $=$ 0.18 . Medial vertical seta closer to lateral vertical seta and slightly towards outer edge of orbital plate, vt index $=0.19$; or 1 -or 3 ratio $=1$, or 2 -or 1 ratio $=0.91$. Ocellar triangle brown, ocellus yellow; frontal triangle yellowish brown. Frontal vitta yellowish brown. Gena and postgena yellow, cheek index $=9.5$. Vibrissa prominent, vibrissa index $=0.27$. Carina prominent and not sulcate. Proboscis yellow. Eyes scarlet, eye index $=4.02$.

THORAx. Yellowish brown, thorax length $0.94 \mathrm{~mm}$, acrostichal hairs in seven rows between two anterior dorsocentral setae, $\mathrm{h}$ index $=1.37 \mathrm{dc}$ index $=0.82$. Scutellum yellow; basal scutellar setae divergent, scut index $=1.12$. Medial katepisternal seta same size as anterior, sterno index $=0.51$. Legs yellow.

Wings. Transparent yellow, bM-Cu slightly clouded (Fig. 1A). Alar length $2.51 \mathrm{~mm}$, alar width $1.10 \mathrm{~mm}$. Alar indices: $\mathrm{alar}=2.26 ; \mathrm{C}=4.21 ; \mathrm{a} \mathrm{c}=1.68 ; \mathrm{hb}=0.47 ; 4 \mathrm{c}=0.6 ; 4 \mathrm{v}=1.42 ; 5 \mathrm{x}=1.08$; $\mathrm{M}=0.38$ and prox. $\mathrm{x}=0.58$.
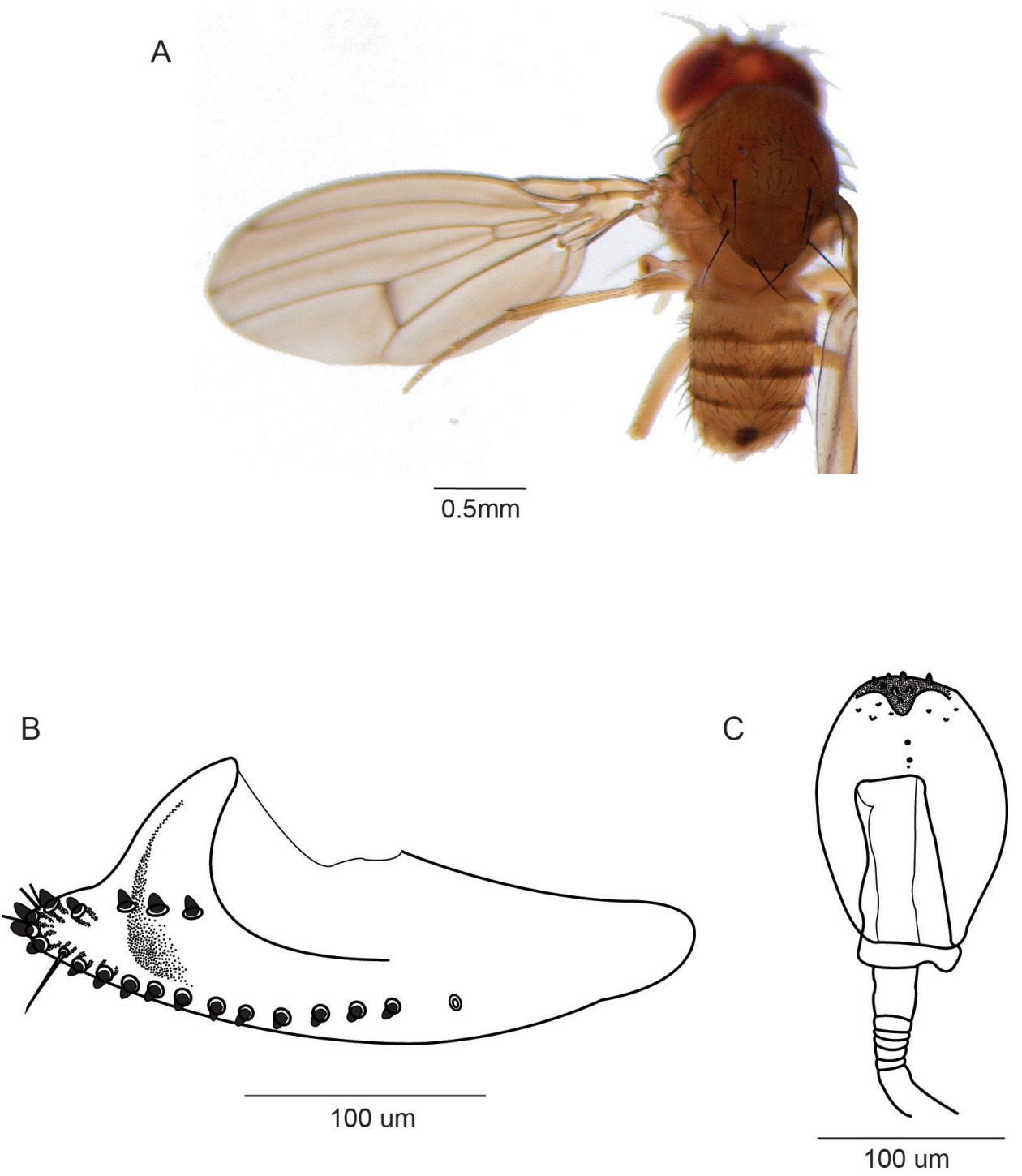

Fig. 1. Drosophila warmi sp. nov. Holotype, o (QCAZ-I 3344). A. Abdomen and wing, dorsal view. B. Ovipositor. C. Spermatheca. 
AвDomen. Yellow with dorsal midline, $1^{\text {st }}$ tergite yellow, $2^{\text {nd }}$ to $4^{\text {th }}$ tergites with thin pigmented bands, $5^{\text {th }}$ and $6^{\text {th }}$ with a median spot between both tergites (Fig. 1A).

Terminalia. Ovipositor sclerotized, slipper-shaped, with 15 marginal and five discal teeth, one long bristle and three fine hairs (Fig. 1B). Spermatheca sclerotized, balloon-shaped, with a distal dimple covered in short spines (Fig. 1C).
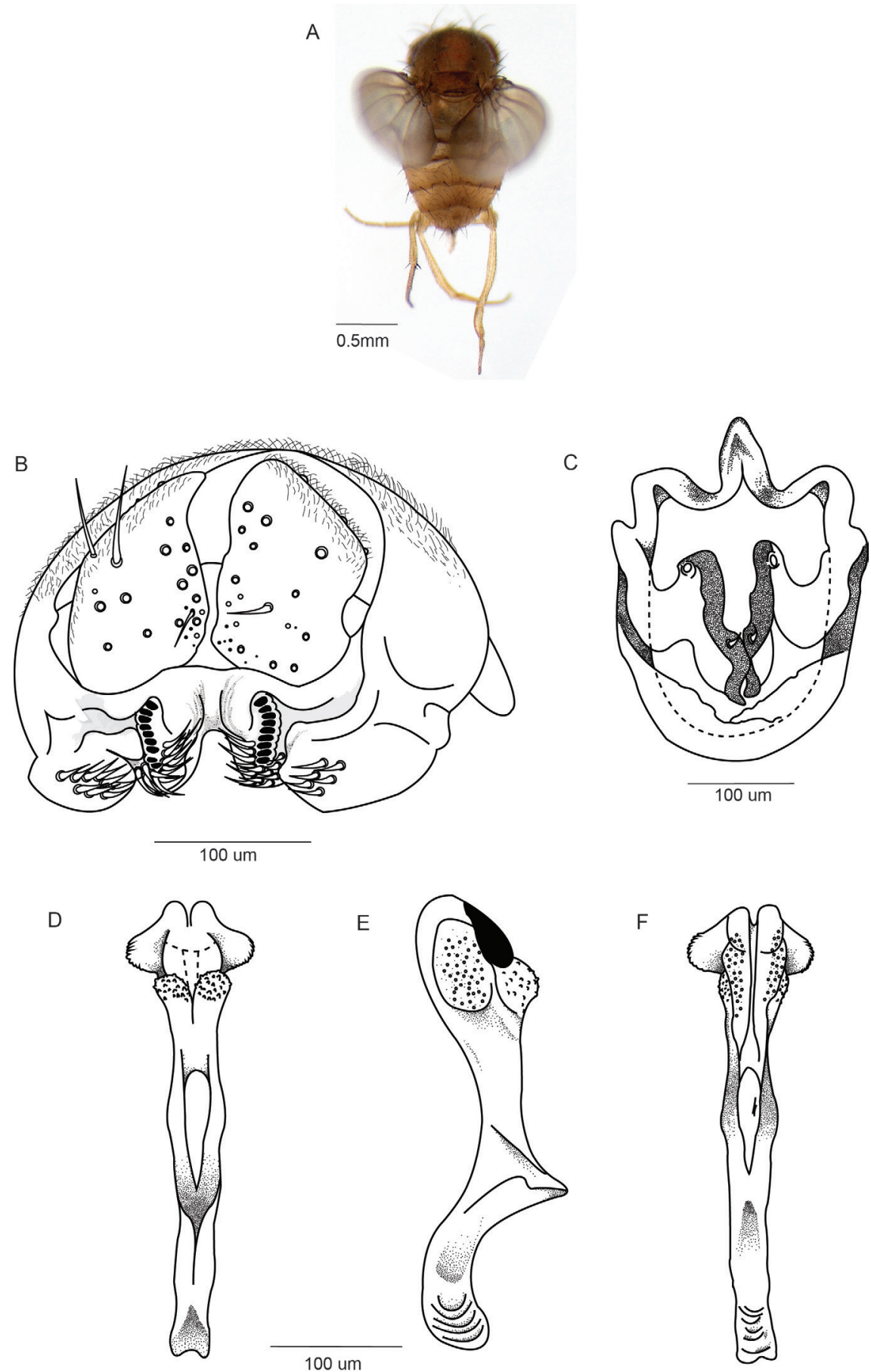

Fig. 2. Drosophila warmi sp. nov. Allotype, ồ (QCAZ-I 3345). A. Abdomen, dorsal view. B. Epandrium, cerci, surstylus, decasternum. C. Hypandrium, gonopods and paraphyses in ventral view. D-F. Aedeagus in ventral, lateral and dorsal view, respectively. 
Variation in paratypes (dry mounted specimens)

Head: frontal length $0.26-0.32 \mathrm{~mm}$, frontal index $=0.63-0.72$, top to bottom width ratio $=0.13-0.22$; vt index $=0.14-0.22$, or $1-$ or 3 ratio $=0.84-1.33$, or $2-$ or 1 ratio $=0.67-1.27$; cheek index $=8.71-12.4$; vibrissa index $=0.14-0.39$; eye index $=2.2-3.87$. Thorax: $\mathrm{h}$ index $=0.70-2.2$, $\mathrm{dc}$ index $=0.74-0.82$; scut index $=1.12-1.47$; sterno index $=0.51-0.66$.

\section{Male}

Reared from an isofemale line. Only two males emerged and both died crushed into the culture media. Morphologically with same characteristics as female except for abdomen, which is yellow and with a faint tiny spot on $6^{\text {th }}$ tergite (Fig. 2A).

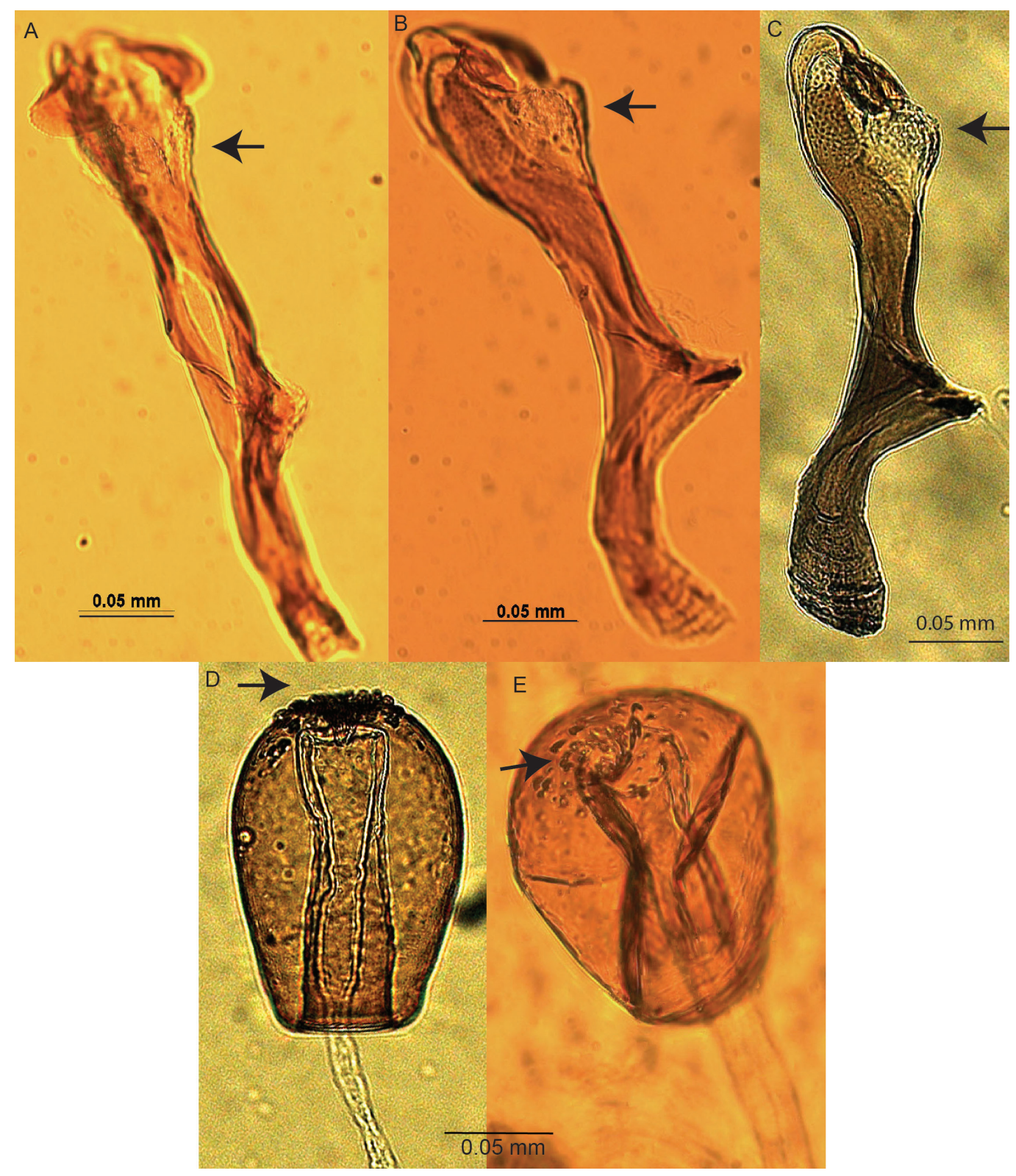

Fig. 3. Drosophila warmi sp. nov. A-C. Allotype, ô (QCAZ-I 3345), aedeagus in ventro-lateral to lateral view, respectively; arrows show the two lateral sclerotized projections. D. Holotype, $q$ (QCAZ-I 3344), spermatheca; arrow shows the centrodistal spines. E. Paratype, q (QCAZ-I 33XX), spermatheca; arrow shows the centrodistal spines. 
Male terminalia. Epandrium dorsally microtrichose, ventral lobe with 9 bristles on right and 6 on left side. Cerci not fused to epandrium, dorsally microtrichose. Surstylus with 9 primary teeth and 13 marginal bristles on right side and 14 on left (Fig. 2B). Hypandrium shield-shaped, with sclerotized edge. Gonopod U-shaped, with some bright studs, bearing one thick bristle (Fig. 2C).

Aedeagus. Tubular and bifid, with two lateral sclerotized and serrated projections, below these projections with two ventral, membranous enlargements covered in bright studs. Aedeagal apodeme shorter than aedeagus. Ventral rod slightly developed (Fig. 2D-F). Paraphyses fused to gonopod, bearing one small bristle.

\section{Distribution}

Known only from the type locality.

\section{Relationship to other species}

This species belongs to subgroup II of the tripunctata group. The most similar species is Drosophila cuaso Bächli, Vilela \& Ratcov, 2000.

Subgroup IV sensu Frota Pessoa 1954

Drosophila kurillakta sp. nov. urn:lsid:zoobank.org:act:DA3AF41D-2B1A-477D-B081-1F6E809A9AD2

Fig. 4

\section{Diagnosis}

Aristae with 6 dorsal and 3 ventral branches plus terminal fork. Vibrissa prominent. Thorax yellowish brown. Legs yellow. Wings yellow, bM-Cu clouded. Cerci not fused to epandrium. Hypandrium shieldshaped. Paraphyses microtrichose, fused to gonopod. Gonopod elongate bearing one long bristle. Aedeagus with sclerotized and membranous areas, and two lateral sclerotized and serrated projections, strongly flattened laterally.

\section{Etymology}

In the Kichwa language, 'kurillakta' refers to 'kuri' = 'gold', and 'llakta' = 'land'. Zamora Chinchipe Province is known for its gold mines. It is therefore called the land of gold.

\section{Material examined}

\section{Holotype}

ECUADOR - $\widehat{\delta}$ (dissected, terminalia in microvial, dry mounted); Zamora Chinchipe Prov., San Francisco, 2190 m a.s.l.; 0359'16.7" S, 7905'35" W; 23 Apr. 2015; A. Peñafiel leg.; A. Peñafiel and V. Rafael det.; QCAZ-I 3355.

\section{Description}

\section{Male}

Holotype external morphology: total length (body + wings) $3.84 \mathrm{~mm}$, body length $3 \mathrm{~mm}$. Body color yellow.

HEAD. Aristae with 6 dorsal and 3 ventral branches plus terminal fork and small hairs, flagellomere yellowish brown. Orbital plate yellowish brown, frontal length $0.39 \mathrm{~mm}$, frontal index $=0.84$, top to bottom width ratio $=1.39$. Medial vertical seta closer to lateral vertical seta and slightly towards outer edge of orbital plate, vt index $=0.4$, or $1-$ or 3 ratio $=0.84$, or $2-$ or 1 ratio $=0.59$. Ocellar triangle brown, 
ocellus yellow; frontal triangle yellowish brown. Frontal vitta yellowish brown. Gena and postgena yellowish brown, cheek index $=5.9$. Vibrissa prominent, vibrissa index $=0.38$. Carina not sulcate. Proboscis yellow. Red eyes, eye index $=1.20$.

THORAX. Yellowish brown, acrostichal hairs in 6 rows between two anterior dorsocentral setae, $\mathrm{h}$ index could not be calculated (broken setae on holotype), $\mathrm{dc}$ index $=0.63$. Scutellum yellowish brown, basal scutellar setae divergent, scut index $=1.45$. Medial katepisternal seta slightly smaller than anterior, sterno index $=1.16$. Legs yellow.

Wings. Yellow, bM-Cu clouded. Alar length $3.34 \mathrm{~mm}$, alar width $1.35 \mathrm{~mm}$. Alar indices: alar = 2.47; $\mathrm{C}=4.32 ; \mathrm{ac}=2.24 ; \mathrm{hb}=0.33 ; 4 \mathrm{c}=0.49 ; 4 \mathrm{v}=1.19 ; 5 \mathrm{x}=0.94 ; \mathrm{M}=0.28$ and prox. $\mathrm{x}=0.33$.
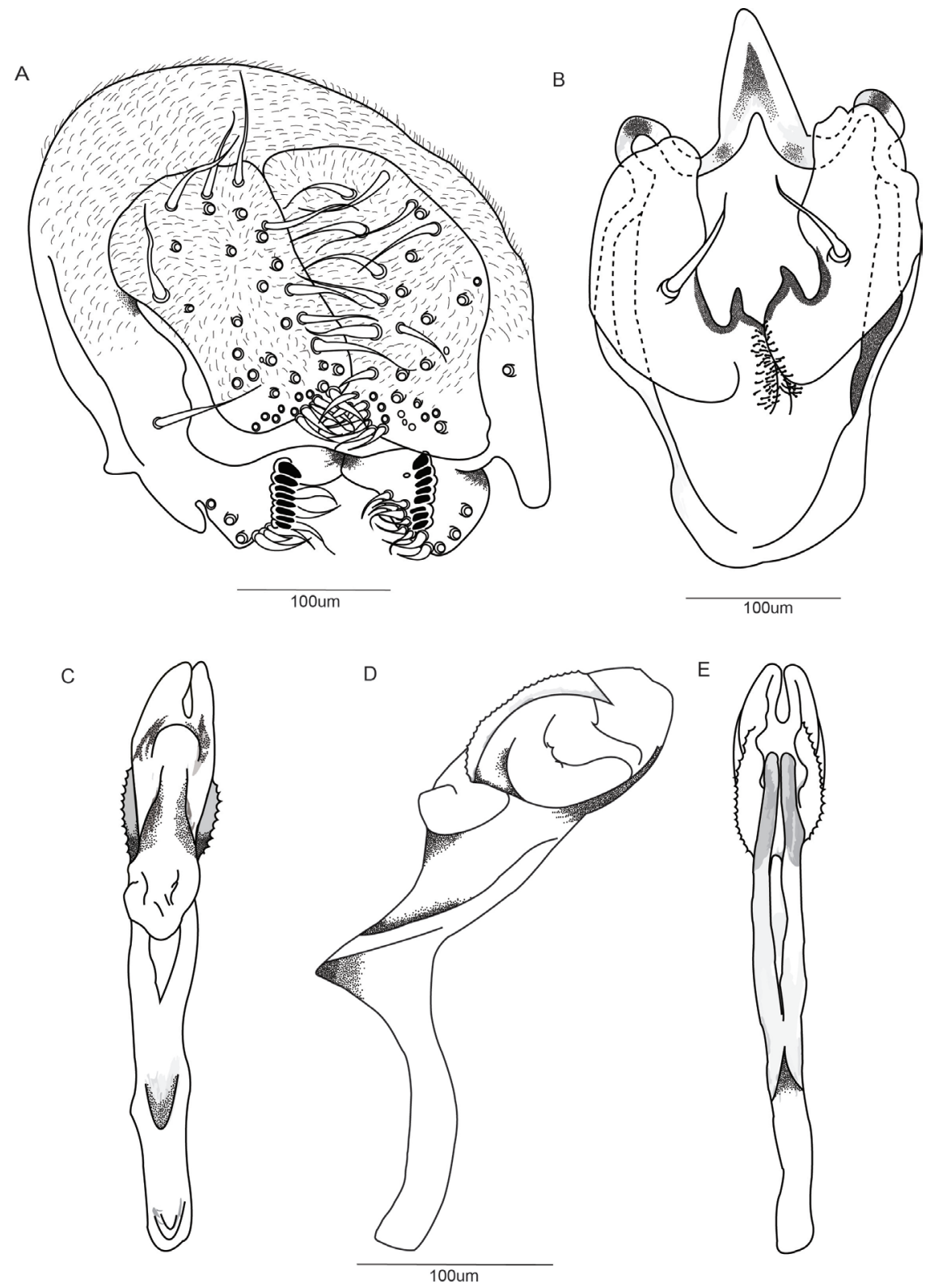

Fig. 4. Drosophila kurillakta sp. nov. Holotype, đ̊ (QCAZ-I 3355). A. Epandrium, cerci, surstylus, decasternum. B. Hypandrium, gonopods and paraphyses in ventral view. C-E. Aedeagus in ventral, lateral and dorsal view, respectively. 
AвDOMEN. Unknown, holotype in poor condition.

MALE TERMinalia. Epandrium microtrichose, ventral lobe bearing one bristle. Surstylus triangular with 8 primary teeth on each side, on left side a gap between $5^{\text {th }}$ and $6^{\text {th }}$ teeth; 9 marginal bristles on right side and 12 on left (Fig. 4A). Hypandrium sclerotized, shield-shaped, same size as epandrium. Gonopod elongate, bearing one long bristle (Fig. 4B).

Aedeagus. Distally widened with a deep cleft, with sclerotized and membranous areas, and two lateral sclerotized and serrated projections, strongly flattened laterally. Ventral rod barely noticeable. Aedeagal apodeme membranous (Fig. 4C-E). Paraphyses sclerotized and microtrichose, fused to gonopod.

\title{
Distribution
}

Known only from the type locality.

\section{Relationship to other species}

This species belongs to subgroup IV of the tripunctata group. The general shape of the male terminalia suggests a relationship with Drosophila loewi Vilela \& Bächli, 2000 from Yucatán, Mexico.

\author{
Not assigned to subgroup \\ Drosophila chichu sp. nov. \\ urn:1sid:zoobank.org:act:3F0DBF0C-E97E-4291-AE59-E298DC96AF7A
}

Fig. 5

\section{Diagnosis}

Aristae with 5 dorsal and 2 ventral branches plus terminal fork. Two prominent oral bristles, $2^{\text {nd }}$ slightly smaller than $1^{\text {st }}$. Thorax yellowish brown. Legs yellowish brown. Wings yellowish brown, dM-Cu slightly clouded. Abdomen yellow with dorsal midline, from $2^{\text {nd }}$ to $5^{\text {th }}$ tergites with triangular pigmentation which becomes thinner laterally, $6^{\text {th }}$ tergite with median spot. Cerci not fused to epandrium. Hypandrium shield-shaped. Gonopod bearing one long bristle. Aedeagus sclerotized and tubular, with a basal ventral bump, ventrally with an apical concavity. Paraphyses fused to gonopod bearing one bristle.

\section{Etymology}

In the Kichwa language, 'chichu' = 'pregnant'. The aedeagus has a ventral bump which resembles a woman's pregnant abdomen.

\section{Material examined}

\section{Holotype}

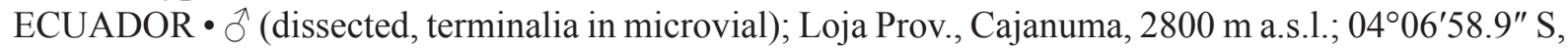
79¹0'11.9" W; 19 Nov. 2015; A. Peñafiel leg.; A. Peñafiel and V. Rafael det.; QCAZ-I 3356.

\section{Paratype}

ECUADOR $\bullet 1 \hat{\jmath}$ (dissected, terminalia in microvial); same data as for holotype; QCAZ-I 3357.

\section{Description}

\section{Male}

Holotype external morphology: total length (body + wings) $4.67 \mathrm{~mm}$, body length $3.56 \mathrm{~mm}$. Body color yellowish brown. 
HeAD. Aristae with 5 dorsal and 2 ventral branches plus terminal fork and small hairs. Orbital plate yellowish brown, frontal length $0.33 \mathrm{~mm}$; frontal index $=0.68$, top to bottom width ratio $=1.35$. Medial vertical seta closer to lateral vertical seta, vt index $=0.87$; or $1-$ or 3 and or $2-$ or 1 ratio could not be calculated (broken setae on holotype). Ocellar triangle yellowish brown, ocellus yellow. Cheek index = 6.5. Two oral bristles, $2^{\text {nd }}$ slightly smaller than $1^{\text {st }}$ bristle, vibrissa index $=1.07$. Carina not sulcate. Red eyes. Eye index $=1.20$.

A

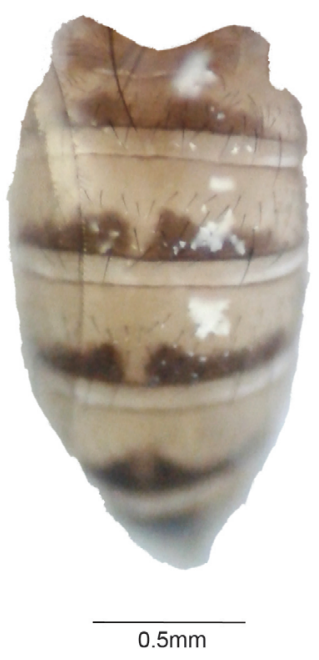

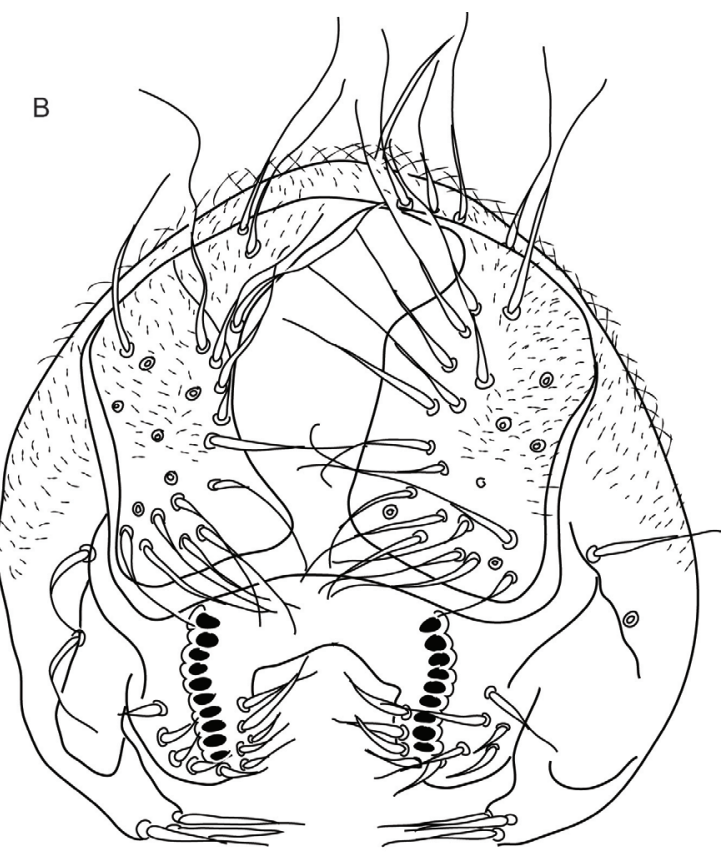

100um

C

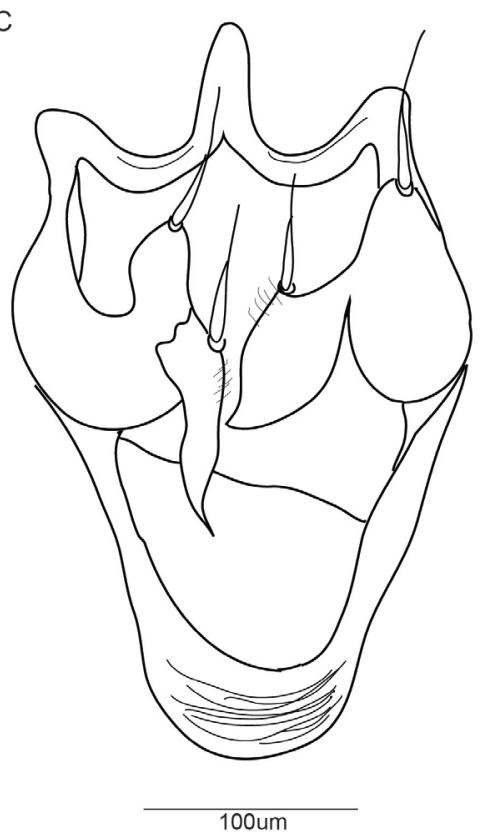

$\mathrm{D}$

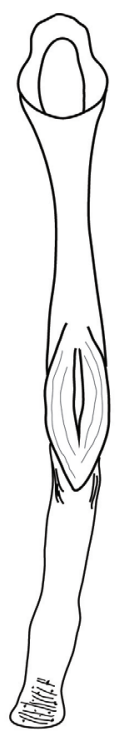

$\mathrm{E}$

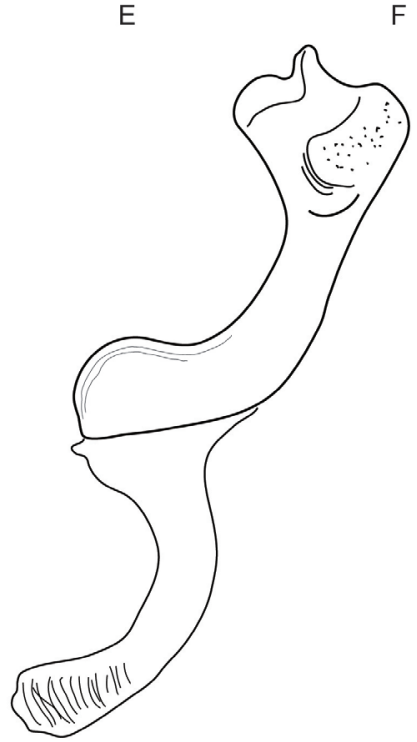

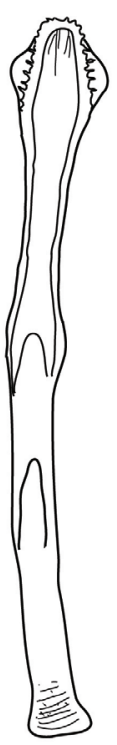

100um

Fig. 5. Drosophila chichu sp. nov. Holotype, ô (QCAZ-I 3356). A. Abdomen. B. Epandrium, cerci, surstylus, decasternum. C. Hypandrium, gonopods and paraphyses in ventral view. D-F. Aedeagus in ventral, lateral and dorsal view, respectively. 
THORAx. Yellowish brown, thorax length $0.89 \mathrm{~mm}$, acrostichal hairs in 2 rows between two anterior dorsocentral setae. $\mathrm{h}$ index $=0.79$; dc index could not be calculated (broken setae on holotype). Medial katepisternal seta slightly smaller than anterior seta. Legs yellowish brown.

Wings. Yellowish brown, dM-Cu slightly clouded. Alar length $2.86 \mathrm{~mm}$, alar width $1.33 \mathrm{~mm}$. Alar indices: alar $=2.12 ; \mathrm{C}=3.24 ; \mathrm{ac}=2.10 ; \mathrm{hb}=0.19 ; 4 \mathrm{c}=0.64 ; 4 \mathrm{v}=1.22 ; 5 \mathrm{x}=1.42 ; \mathrm{M}=0.42$ and prox. $\mathrm{x}=0.41$.

ABdomen. Yellow with dorsal midline, $1^{\text {st }}$ tergite yellowish brown, $2^{\text {nd }}$ to $5^{\text {th }}$ tergites with triangular pigmentation which becomes thinner laterally, $6^{\text {th }}$ tergite with a median spot (Fig. 5A).

Male terminalia. Epandrium dorsally microtrichose, with 2 lower bristles, ventral lobe with 3 bristles on each side. Cerci microtrichose and not fused to epandrium. Surstylus with 10 primary teeth on right side and 9 on left, 10 marginal bristles on each side (Fig. 5B). Hypandrium shield-shaped, slightly sclerotized. Gonopod bearing one bristle (Fig. 5C).

Aedeagus. Sclerotized and tubular with a basal ventral bump, ventrally with an apical concavity, dorsally membranous, with bright studs. Ventral rod absent. Paraphyses fused to gonopod bearing one bristle. Aedeagal apodeme sclerotized and curved (Fig. 5D-F).

\section{Distribution}

Known only from the type locality.

\section{Relationship to other species}

This species belongs to the tripunctata group. The general shape of the male terminalia, particularly that of the aedeagus, suggests a relationship with D. cundinamarca Vilela \& Bächli, 2000 and D. pilaresae Vela \& Rafael, 2001.

\section{Drosophila saraguru sp. nov. urn:1sid:zoobank.org:act:056F4DE6-85EE-436D-8E7C-DC300DF233F8}

Fig. 6

\section{Diagnosis}

Aristae with 5 dorsal and 2 ventral branches plus terminal fork. One prominent oral bristle. Thorax yellowish brown. Legs yellow. Abdomen yellow with dorsal midline, $2^{\text {nd }}$ to $4^{\text {th }}$ tergites with triangular pigmentation which becomes thinner laterally, $5^{\text {th }}$ and $6^{\text {th }}$ tergites with a median spot. Cerci not fused to epandrium. Hypandrium shield-shaped. Gonopod bearing one long bristle. Paraphyses fused to gonopod, bearing one small bristle. Aedeagus voluminous, dorsoapically membranous, apex rounded, and two lateral sclerotized, corrugated and serrated projections.

\section{Etymology}

Named in recognition of the Saraguro people. They are a people of indigenous Kichwas in the Ecuadorian highlands. They live mainly in the south of Ecuador in Loja Province, relocated from an unknown location in Perú by the Inca in pre-Hispanic times. The word comes from the Kichwa words 'sara' = 'corn' and ' $\mathrm{guru}$ ' = 'worm'.

\section{Material examined}

\section{Holotype}

ECUADOR • $\widehat{O}$ (dissected, terminalia in microvial); Loja Prov., Cajanuma, $2675 \mathrm{~m}$ a.s.1.; 04 06'53.7" S, 79¹0'54.6" W; 19 Nov. 2015; A. Peñafiel leg.; A. Peñafiel and V. Rafael det.; QCAZ-I 3358. 


\section{Paratype}

ECUADOR • 1 ○े (dissected, terminalia in microvial); same data as for holotype; QCAZ-I 3359.

\section{Description}

\section{Male}

Holotype external morphology: total length (body + wings) $4.45 \mathrm{~mm}$, body length $2.96 \mathrm{~mm}$. Body color yellowish brown.

HeAD. Aristae with 5 dorsal and 2 ventral branches plus terminal fork and fine hairs. Orbital plate yellowish brown, frontal length $0.32 \mathrm{~mm}$; frontal index $=1$; top to bottom width ratio $=1.58$. Medial
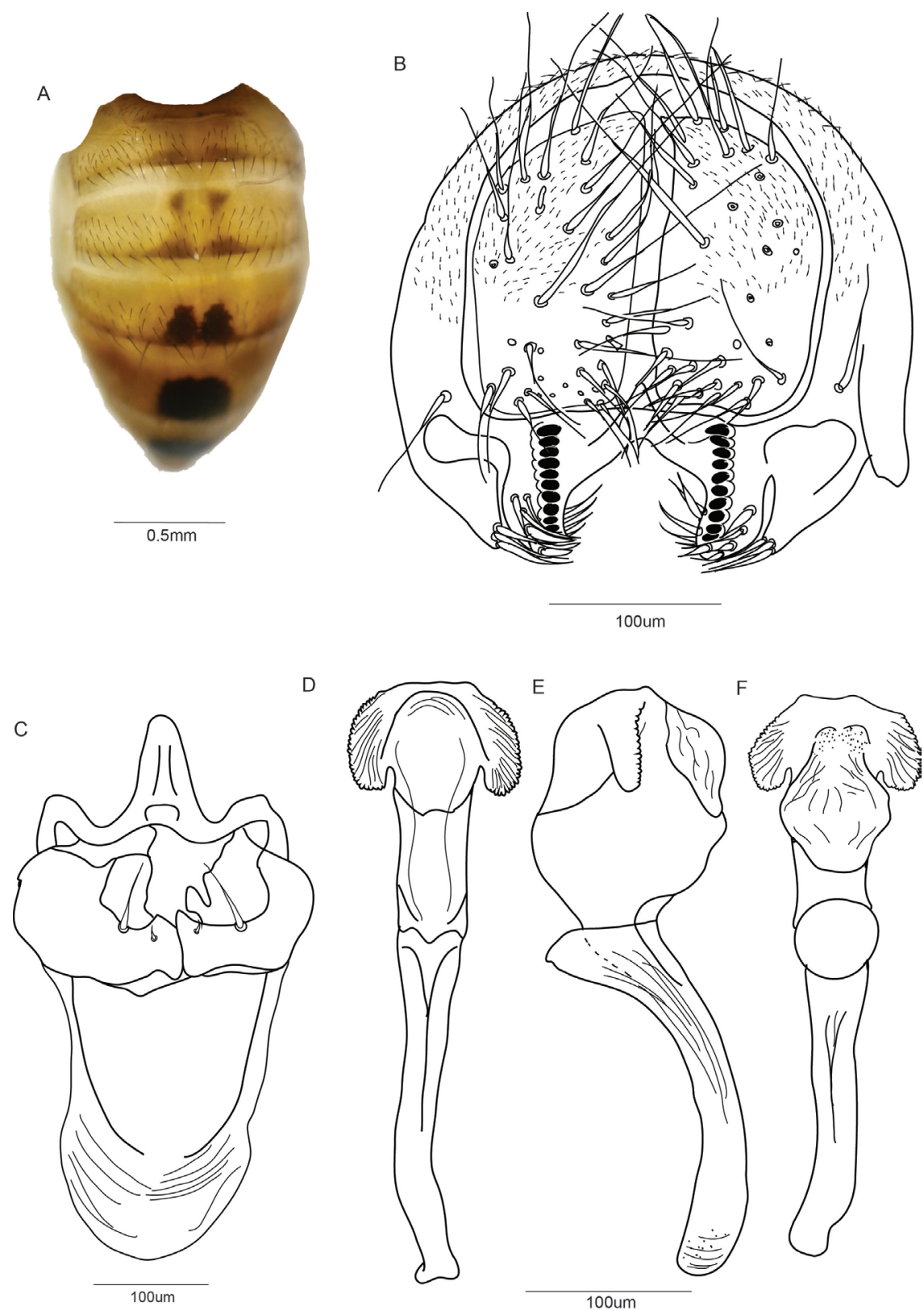

Fig. 6. Drosophila saraguru sp. nov. Holotype, $\widehat{\partial}$ (QCAZ-I 3358). A. Abdomen. B. Epandrium, cerci, surstylus, decasternum. C. Hypandrium, gonopods and paraphyses in ventral view. D-F. Aedeagus in ventral, lateral and dorsal view, respectively. 
vertical seta closer to lateral vertical seta, vt index $=0.79$; or $1-$ or 3 ratio $=0.88$, or 2 -or 1 ratio $=0.42$. Ocellar triangle brown, ocellus yellow. Frontal vitta yellowish brown. Cheek index $=6.5$. One prominent oral bristle, vibrissa index $=0.4$. Carina not sulcate. Eyes yellowish red. Eye index $=1.70$.

THORAX. Yellowish brown, thorax length $0.96 \mathrm{~mm}$, acrostichal hairs in 6 rows between two anterior dorsocentral setae. $\mathrm{h}$ index $=1.13$; dc index $=0.65$. Scut index $=1.16$. Medial katepisternal seta $1 / 2$ length of anterior; sterno index $=1.8$. Legs yellow.

Wings. Yellow. Alar length $3.19 \mathrm{~mm}$, alar width $1.35 \mathrm{~mm}$. Alar indices: alar $=2.36$; $\mathrm{C}=4.49$; ac $=1.59$; $\mathrm{hb}=0.29 ; 4 \mathrm{c}=0.47 ; 4 \mathrm{v}=1.21 ; 5 \mathrm{x}=0.91 ; \mathrm{M}=0.28$ and prox. $\mathrm{x}=0.36$.

Aвdomen. Yellow with dorsal midline, $1^{\text {st }}$ tergite yellowish brown, $2^{\text {nd }}$ to $4^{\text {th }}$ tergites with triangular pigmentation which becomes thinner laterally, $5^{\text {th }}$ and $6^{\text {th }}$ tergites with a median spot (Fig. 6A).

Male terminalia. Epandrium microtrichose, with 1 lower and no upper bristles, ventral lobe of epandrium with 3 grouped bristles. Surstylus with 10 primary teeth and 10 marginal bristles on each side. Cerci not fused to epandrium (Fig. 6B). Hypandrium shield-shaped and sclerotized. Gonopod bearing one long bristle (Fig. 6C).

AEDEAgus. Voluminous, dorsoapically membranous, apex rounded, with two lateral sclerotized, earshaped, corrugated and serrated projections. Aedeagal apodeme sclerotized, elongated and curved (Fig. 6D-F). Paraphyses fused to gonopod, bearing one small bristle (Fig. 6C).

\section{Distribution}

Known only from the type locality.

\section{Relationship to other species}

This species belongs to the tripunctata group.

$$
\begin{gathered}
\text { Drosophila ayauma sp. nov. } \\
\text { urn:1sid:zoobank.org:act:5CEBC281-6F5E-41B8-B837-03ABF2237494 }
\end{gathered}
$$

Fig. 7

\section{Diagnosis}

Body color yellowish brown. Aristae with four dorsal and two ventral branches. Two prominent oral bristles plus terminal fork. Thorax yellowish brown. Abdomen yellow with dorsal midline, $2^{\text {nd }}$ to $5^{\text {th }}$ tergites with triangular pigmentation that thins laterally. Cerci not fused to epandrium. Aedeagus wide, with two dorsal sclerotized projections ending in a point, ventrally with two sclerotized rounded sheets. Hypandrium shield-shaped. Gonopod bearing one long bristle. Paraphyses microtrichose, fused to gonopod, bearing one small bristle.

\section{Etymology}

The name 'ayauma' comes from Kichwa 'aya' = 'spirit' and 'uma' = 'head', meaning 'spirit from the head'. The apex of the aedeagus resembles two demon horns.

\section{Material examined}

\section{Holotype}

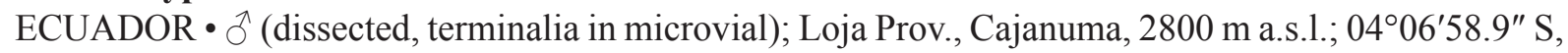
79¹0'11.9" W; 19 Nov. 2015; A. Peñafiel leg.; A. Peñafiel and V. Rafael det.; QCAZ-I 3336. 
Paratypes

ECUADOR $\bullet 6$ ठึ (dissected, terminalia in microvial); same data as for holotype; QCAZ-I 3337 to 3342 - 1 ô (dissected, terminalia in microvial); Napo Prov., Río Guango, $2548 \mathrm{~m}$ a.s.1.; 00³2'44.0" S, 7757'13.4" W; 19 Sep. 2015; A.B. Manzano leg.; A. Peñafiel and V. Rafael det.; QCAZ-I 3343.

\section{Description}

\section{Male}

Holotype external morphology: total length (body + wings) $7.43 \mathrm{~mm}$, body length $4.22 \mathrm{~mm}$. Body color yellowish brown.

Head. Aristae with 4 dorsal and 2 ventral branches plus terminal fork and fine hairs. Orbital plate yellowish brown, frontal length $0.37 \mathrm{~mm}$; frontal index $=1.02$; top to bottom width ratio $=1.51$. Medial vertical seta closer to lateral vertical seta and slightly towards outer edge of orbital plate; vt index $=$ 0.86 ; or $1-$ or 3 ratio $=0.74$; or $2-$ or 1 ratio $=0.43$. Ocellar triangle brown, ocellus yellow, frontal vitta yellowish brown. Cheek index $=5.9$. Two prominent oral bristles of same size, vibrissa index $=0.78$. Carina yellowish brown, not sulcate. Eyes bright red, eye index $=1.66$.

THorax. Yellowish brown, acrostichal hairs in 8 rows between two anterior dorsocentral setae that decrease in number towards rear. $\mathrm{h}$ index $=1.27$; $\mathrm{dc}$ index $=0.83$. Scut index $=1.09$. Medial katepisternal seta same size as previous seta, sterno index $=1.47$. Legs yellow.

Wings. Brown. Alar length $3.55 \mathrm{~mm}$, alar width $1.51 \mathrm{~mm}$. Alar indices: alar $=2.26 ; \mathrm{C}=4.98 ; \mathrm{ac}=1.78$; $\mathrm{hb}=0.20 ; 4 \mathrm{c}=0.43 ; 4 \mathrm{v}=1.20 ; 5 \mathrm{x}=1.15 ; \mathrm{M}=0.32$ and prox. $\mathrm{x}=0.34$.

Aвdomen. Yellow with dorsal midline, $1^{\text {st }}$ tergite brown and $2^{\text {nd }}$ to $5^{\text {th }}$ tergites with triangular pigmentation that thins laterally (Fig. 7A).

MALE TERMinALIA. Epandrium dorsally microtrichose, with no upper or lower bristles, ventral lobe fused to surstylus by a membrane bearing one long bristle. Cerci not fused to epandrium, ventral side not microtrichose and with several long bristles towards middle. Surstylus with 9 primary teeth on each side, 15 marginal bristles on right and 14 on left (Fig. 7B). Hypandrium sclerotized, shield-shaped (Fig. 7C).

AEDEAGUs. Wide, with two dorsal sclerotized projections ending in a point, ventrally with two sclerotized rounded sheets, middle part of aedeagus membranous, covered in bright studs. Ventral rod primitive. Aedeagus apodeme slightly sclerotized and straight. Gonopod microtrichose, bearing one long bristle (Fig. 7D-F). Paraphyses microtrichose, fused to gonopod, bearing one small bristle (Fig. 7C).

Variation in paratypes (dry mounted specimens)

Abdomen: other specimens show triangular pigmentation that thins laterally and then reaches and covers exterior margin of each tergite. Head: frontal length $0.22-0.42 \mathrm{~mm}$, frontal index $=0.53-0.84$, top to bottom width ratio $=1.2-1.66$; cheek index $=5-7.57$; vibrissa index $=0.45-0.78$; eye index $=1.15-1.64$.

\section{Distribution}

Known from the type locality and from the montane forest of Río Guango at $2548 \mathrm{~m}$ a.s.1.

\section{Relationship to other species}

The general shape of the male terminalia does not suggest any relationship to other described species of the Drosophila tripunctata group. 


\section{Discussion}

Drosophila warmi sp. nov. is very similar to D. cuaso Bächli, Vilela \& Ratcov, 2000; nevertheless, there are some differences in the aedeagus. Both species share the character of having two lateral sclerotized and serrated projections on the aedeagus. Drosophila warmi sp. nov. has two ventral membranous enlargements covered in bright studs, that noticeably split in two (Fig. 3A-C), while D. cuaso has a ventral membranous rounded surface also covered in bright studs. According to Bächli et al. (2000), $D$. cuaso always bears, in males and females, one well outlined and relatively large, black or coffee brown spot on the middle area of the $6^{\text {th }}$ tergite. In $D$. warmi sp. nov., there is a faint tiny spot on the $6^{\text {th }}$ tergite of males. In females of $D$. cuaso, the spot never reaches the anterior or posterior margin, but

A
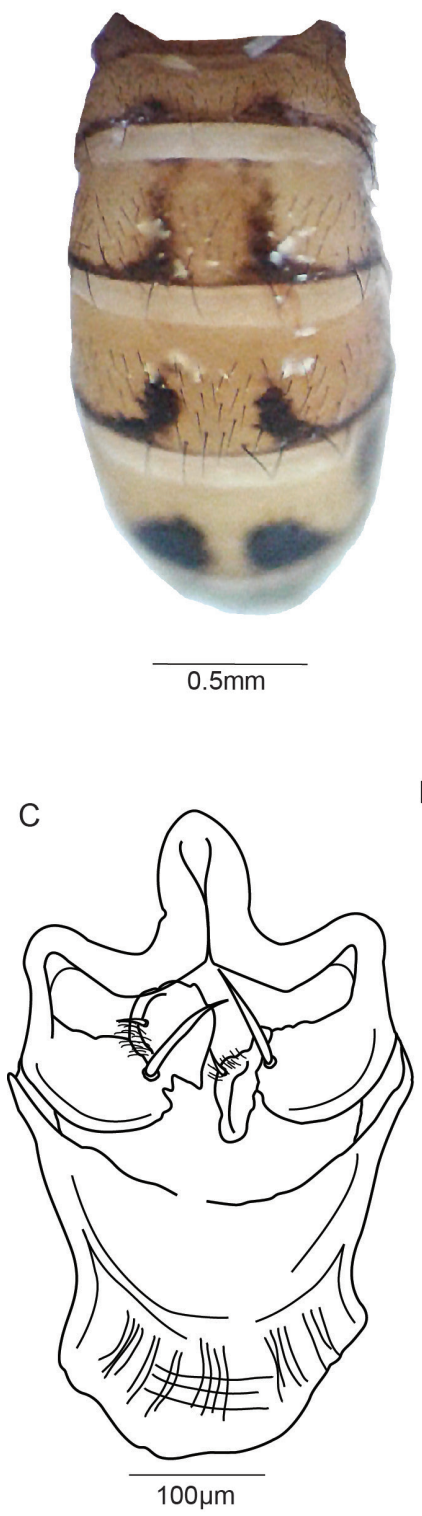

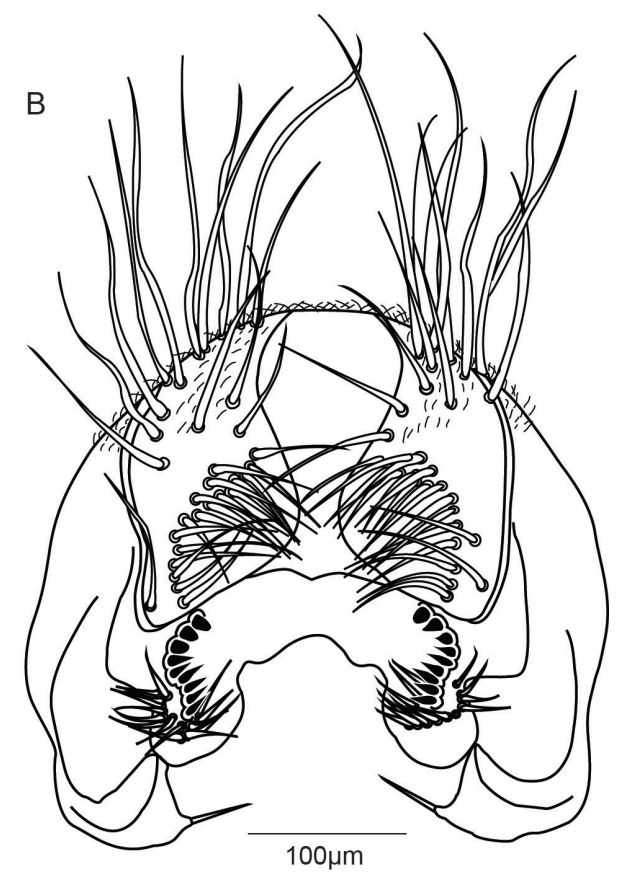

$\mathrm{D}$

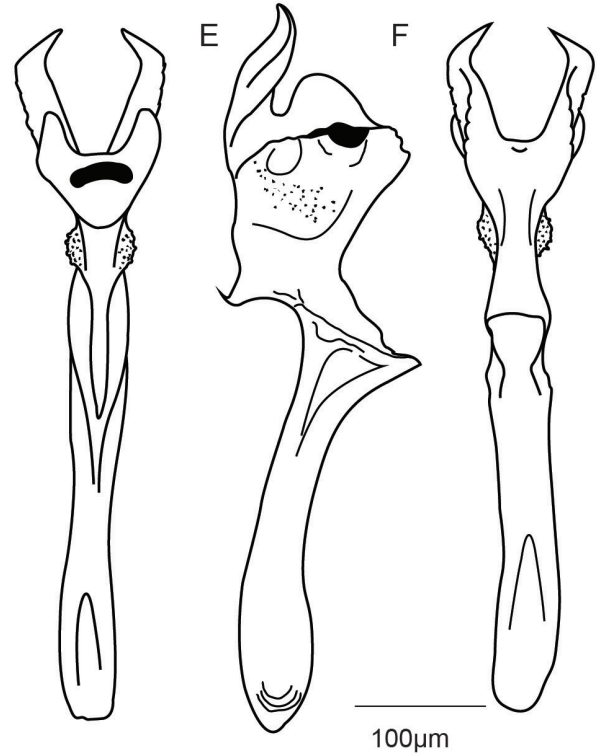

Fig. 7. Drosophila ayauma sp. nov. Holotype, ठ̊ (QCAZ-I 3336). A. Abdomen. B. Epandrium, cerci, surstylus, decasternum. C. Hypandrium, gonopods and paraphyses in ventral view. D-F. Aedeagus in ventral, lateral and dorsal view, respectively. 
in $D$. warmi sp. nov. the median spot is shared between the $5^{\text {th }}$ and $6^{\text {th }}$ tergites. The inner spermathecal capsule of $D$. warmi sp. nov. bears about 15-30 centrodistal short spines (Fig. 3D-E), whereas in $D$. cuaso it has 5 spines, although the specimen identified as D. cuaso from Bucaramanga, Colombia, illustrated and identified by Bächli et al. (2000), has many more spines. Regarding the similarities in the number of spermathecal distal spines in the females of $D$. warmi sp. nov. and the specimen from Bucaramanga, Colombia (Bächli et al. 2000), we think that it could have been misidentified, and it could belong to $D$. warmi sp. nov.

Drosophila warmi sp. nov. belongs to subgroup II. This species resembles, in external characters and terminalia, species in the paraguayensis complex (Bächli et al. 2000). The abdominal pigmentation of Drosophila warmi sp. nov. is cryptic with that of species of the paraguayensis complex.

Drosophila kurillakta sp. nov. shares the microtrichose paraphyses and the general shape of the hypandrium with $D$. loewi Vilela \& Bächli, 2000. Although $D$. kurillakta sp. nov. is similar to $D$. loewi, the most important difference is in the aedeagus. First, the aedeagus in D. kurillakta sp. nov. is deeply invaginated at the tip, whereas it is just slightly invaginated at the tip in D. loewi (Vilela \& Bächli 2000). Second, the aedeagus in $D$. loewi is wider than in D. kurillakta sp. nov., which is strongly flattened laterally. Finally, the serrated expansions of the aedeagus in $D$. loewi are located distally, whereas the serrated expansions in D. kurillakta sp. nov. are subapical. There is a slight difference in the paraphyses; $D$. loewi bears one short bristle and D. kurillakta sp. nov. does not have this bristle. Drosophila kurillakta sp. nov. is affiliated with subgroup IV as well as the morphologically related species $D$. loewi.

The similarities between $D$. chichu sp. nov. and D. cundinamarca Vilela \& Bächli, 2000 include external morphological characters and the male terminalia. Both species have a yellowish brown head and thorax; the R-M and dM-Cu cross-veins of the wings are slightly clouded and the abdomen pigmentation pattern in $D$. cundinamarca and $D$. chich $u$ sp. nov. is similar. On the $2^{\text {nd }}$ to $4^{\text {th }}$ tergites there is a medially interrupted marginal band. The most important similarities of the terminalia, in addition to the general shape of the aedeagus, are in the ventral lobe of the epandrium, which has three grouped setae at the tip, and the aedeagus has a subapical concavity. The main differences between these closely related species are in the terminalia. First, the aedeagus in D. chichu sp. nov. has a particular basal, ventral 'bump'. Second, the aedeagus is membranous dorsally, with bright studs. The paraphyses in D. chichu sp. nov. bear a bristle, but $D$. cundinamarca does not have this bristle.

Drosophila chichu sp. nov. is clearly a member of the tripunctata group because of the external morphology and the general shape of the aedeagus. Despite the general similarities that $D$. chichu sp. nov. has with $D$. cundinamarca, the two species bear little resemblance to any other species assigned to a specific subgroup. In agreement with the criteria of Vilela \& Bächli (2000), we did not assign this species to any subgroup. After a comparison of $D$. chichu sp. nov. with the paratypes of $D$. pilaresae Vela \& Rafael, 2001 and a review of the published description of $D$. cundinamarca, we propose placing these species in a cluster formed by $D$. cundinamarca, D. pilaresae and D. chichu sp. nov., and hereby named the cundinamarca cluster. The diagnostic characteristics of this cluster are the laterally, strongly flattened aedeagus and the ventrally convex and subapically concave shape of the aedeagus. The ventral lobe of the epandrium of these three species has three grouped bristles, which is unique to these three species.

Drosophila saraguru sp. nov. and Drosophila ayauma sp. nov. are not similar to other species in the tripunctata group. They share the important key characters of the tripunctata group. The genitalia characteristics of D. saraguru sp. nov. and D. ayauma sp. nov., including the cerci not being fused to the epandrium, the shield-shaped hypandrium and the general shape of the aedeagus, are characteristic of species in the tripunctata group (Frota-Pessoa 1954). 
Drosophila saraguru sp. nov. and D. ayauma sp. nov. bear little resemblance to any other species assigned to a subgroup; for this reason we are not assigning them to any subgroup.

Finally, the type specimens were found in banana-baited traps placed in the field, or are descendants of isofemale lines, which suggests that these species feed on fermented fruit, as many other species of Drosophila.

\section{Acknowledgements}

This work was supported by the Pontificia Universidad Católica del Ecuador, and is part of the projects L13240 and M1347. The Ecuadorian Ministerio de Ambiente provided research and collection permits $\mathrm{N}^{\circ}$ 003-15IC-FAU-DNB/MA and MAE-DNB-CM-2016-0030. We thank Ana Belén Manzano for providing the paratype of Drosophila ayauma sp. nov. from Río Guango, Fernanda Salazar for her assistance in archiving the specimens in the museum. Dr Clifford Keil provided helpful comments to the manuscript. Dr David Donoso, Luz Marina Llangarí, María Isabel Tamayo and Jonathan Rondal are thanked for their assistance in the field.

\section{References}

Bächli G., Vilela C.R., Andersson Escher S. \& Saura A. 2004. The Drosophilidae (Diptera) of Fennoscandia and Denmark. Fauna Entomologica Scandinavica 39: 1-362.

Bächli G. 2018. TaxoDros: Database on the Taxonomy of Drosophilidae [online]. Available from http://www.taxodros.uzh.ch [accessed 31 Aug. 2018].

Bächli G., Vilela C.R. \& Ratcov V. 2000. Morphological differences among Drosophila paraguayensis Duda, 1927 and its close relatives (Diptera, Drosophilidae). Bulletin de la Société entomologique suisse 73: 67-92.

Céspedes D. \& Rafael V. 2012. Descripción de una nueva especie del grupo Drosophila tripunctata (Diptera: Drosophilidae) en Cruz Loma, Pichincha, Ecuador. Revista Ecuatoriana de Medicina y Ciencias Biológicas 33: 124-128. https://doi.org/10.26807/remcb.v33i1-2.227

Dobzhansky T. \& Pavan C. 1943. Studies on Brazilian species of Drosophila. Boletim da Faculdade de Filosofia, Ciencias e Letras, Universidade de Sao Paulo 36: 7-72.

Duda O. 1927. Die südamerikanischen Drosophiliden (Dipteren) unter Berücksichtigung auch der anderen neotropischen sowie der nearktischen Arten. Archiv für Naturgeschichte 91: 1-228.

Frota-Pessoa O. 1954. Revision of the tripunctata group of Drosophila with description of fifteen new species (Drosophilidae, Diptera). Arquivos do Museu Paranaense 10: 253-304.

Márquez-Luna J. 2005. Técnicas de colecta y preservación de insectos. Boletín de la Sociedad Entomológica Aragonesa 37: 385-408.

Hatadani L.M., McInerney J.O., Medeiros H.F. de, Martins A.C., Azeredo-Espin A.M. de \& Klaczko L.B. 2009. Molecular phylogeny of the Drosophila tripunctata and closely related species groups (Diptera: Drosophilidae). Molecular Phylogenetics and Evolution 51 (3): 595-600.

https://doi.org/10.1016/j.ympev.2009.02.022

Pipkin S.B. \& Heed W.B. 1964. Nine new members of the Drosophila tripunctata species group (Diptera: Drosophilidae). Pacific Insects 6 (2): 256-273.

Rafael V., Arcos G. \& Arcos L. 2000. Ecología y distribución del género Drosophila en Guayllabamba y el Quinche, provincia de Pichincha-Ecuador. Revista de la Pontificia Universidad Católica del Ecuador 65: $130-155$. 
Ramos E. \& Rafael V. 2015. Three new species of Drosophila tripunctata group (Diptera: Drosophilidae) in the eastern Andes of Ecuador. Revista Peruana de Biología 22 (3): 289-296.

https://doi.org/10.15381/rpb.v22i3.11433

Robe L.J., Valente V.L., Budnik M. \& Loreto E.L. 2005. Molecular phylogeny of the subgenus Drosophila (Diptera, Drosophilidae) with an emphasis on Neotropical species and groups: a nuclear versus mitochondrial gene approach. Molecular Phylogenetics and Evolution 36: 623-640. https://doi.org/10.1016/j.ympev.2005.05.005

Sturtevant A. 1921. The North American Species of Drosophila. Publication 301, Carnegie Institute, Washington DC.

Sturtevant A. 1942. The classification of the genus Drosophila, with descriptions of nine new species. University of Texas Publications 4213: 5-51. Available from http://hdl.handle.net/2152/27735 [accessed 20 Jan. 2019].

Throckmorton L.H. 1975. The phylogeny, ecology and geography of Drosophila. In: King R.C. (ed.) Handbook of Genetics 3: 421-469. Plenum Publishing Corporation, New York.

Vela D. \& Rafael V. 2001. Ocho nuevas especies del grupo tripunctata, género Drosophila (Diptera, Drosophilidae), y el registro de Drosophila paraguayensis en el Bosque Protector Pasochoa, Pichincha Ecuador. Revista de la Pontificia Universidad Católica del Ecuador 66: 92-120.

Vela D. \& Rafael V. 2005. Catorce nuevas especies del género Drosophila (Diptera, Drosophilidae) en el bosque húmedo montano del Volcán Pasochoa, Pichincha, Ecuador. Revista Ecuatoriana de Medicina y Ciencias Biológicas 27: 27-41. https://doi.org/10.26807/remcb.v27i1-2.191

Vilela C.R. \& Bächli G. 1990. Taxonomic studies on Neotropical species of seven genera of Drosophilidae (Diptera). Mitteilungen der schweizerischen entomologischen Gesellschaft 63: 1-333.

Vilela C. 1992. On the Drosophila tripunctata species group (Diptera, Drosophidae). Revista Brasileira de Entomologia 36: 197-221.

Vilela C. \& Bächli G. 2000. Five new species of Neotropical Drosophila. Bulletin de la Société entomologique suisse 73: 49-65.

Yokoto K.S.C., Medeiros H.F., Solferini V.N. \& Klaczko L.B. 2003. A molecular study of the systematics of the Drosophila tripunctata group and the tripunctata radiation. Molecular Phylogenetics and Evolution 28: 614-619. https://doi.org/10.1016/S1055-7903(03)00218-5

Manuscript received: 20 July 2018

Manuscript accepted: 13 December 2018

Published on: 1 February 2019

Topic editor: Gavin Broad

Desk editor: Danny Eibye-Jacobsen

Printed versions of all papers are also deposited in the libraries of the institutes that are members of the EJT consortium: Muséum national d'Histoire naturelle, Paris, France; Meise Botanic Garden, Belgium; Royal Museum for Central Africa, Tervuren, Belgium; Natural History Museum, London, United Kingdom; Royal Belgian Institute of Natural Sciences, Brussels, Belgium; Natural History Museum of Denmark, Copenhagen, Denmark; Naturalis Biodiversity Center, Leiden, the Netherlands; Museo Nacional de Ciencias Naturales-CSIC, Madrid, Spain; Real Jardín Botánico de Madrid CSIC, Spain; Zoological Research Museum Alexander Koenig, Bonn, Germany. 